\title{
The development of application for child care services in facilitating distance learning
}

\author{
Rezka Arina Rahma*, M. Ishaq \& Sucipto \\ Department of Nonformal Education, Malang City, Universitas Negeri Malang \\ Yessi Affriyenni \\ Faculty of Mathematics and Natural Sciences, Malang City, Universitas Negeri Malang
}

\begin{abstract}
Child Care (Taman Penitipan Anak/TPA) is a form of nonformal Early Childhood Education (PAUD) services that are continuously growing in line with the needs of today's society. During this Covid-19 pandemic, TPA continues to provide learning services but remotely. Therefore, TPA services need to be extended to reach children's activities at home through distance learning. TPA Melati Dharma Wanita Persatuan is one of the nonformal education. The objectives of this study have developed an application for child care services in Covid-19 pandemic era. This research is used to research and development methods ( R \& D) with 4-D Models. The results showed that the application for child care services is very feasible. The application for child care services received a very good category (88\%) from parents/guardians of students as user regarding convenience, suitability, and usefulness of the application. The service model provided at TPA Melati Dharma Wanita Persatuan UM included care services, educational services, health services, and infrastructure services. The services provided by TPA Melati Dharma Wanita Persatuan UM can be accessed through the application so that students still get care services during the Covid-19 pandemic.
\end{abstract}

Keywords: Application, Child care Service, Covid-19 Pandemic Era

\section{INTRODUCTION}

Children in early childhood are the group of children who are in a unique process of growth and development. They have a specific growth and development pattern that is in proportion to the level of growth and development (Bowman \& Donovan 2010; Yulianingsih et al. 2020). During the early childhood period, a child needs education (Gadsden et al. 2016; Huang et al. 2017; Oostdam \& Hooge 2013). Therefore, children need a variety of services and assistance from adults to meet their physical and non-physical needs, so that children can grow and develop optimally.

However, the rapid changes in the socio-cultural structure have led to increased life needs and economies so that both parents have to work. This condition causes children to be parted from their parents and reducing the span of attention and affection to children. Thus the attachment of parents and children is then lessened. Whilst, in reality, the presence of both parents is very much needed by the children. For this reason, efforts to minimize the unfulfilled needs of children in their early childhood are required. Appropriate care and education for these children are required, as they are related to the role of child care institutions in the community as the temporary substitute of parents, one of which is Child care (TPA) (Ang 2018; Stearns 2019).

Child care is a form of non-formal early childhood education (PAUD) service that is currently growing in number. One of the TPAs in the city of Malang is TPA Melati Dharma Wanita Persatuan UM that provides childcare facilities for children whose parents are busy working outside their

*Corresponding author: rezka.rahma.fip@um.ac.id 
home. Services for parents for children's needs are important, especially in Covid-19 pandemic era. A policy of learning from home, including early childhood, was implemented. Therefore, services are needed for parents who support parenting activities during the Covid-19 pandemic through virtual learning so that children's needs can be fulfilled.

\section{METHOD}

This study used the Research and Development ( $\& \& D)$ method with 4-D (Four-D Models): define, design, develop, and disseminate was adopted from Thiagarajan (Dewi \& Akhlis 2016). The define step, therea are several things to carry out are (1) front end analysis, it is determining the fundamental problems in TPA Melati UM during the Covid-19 pandemic, (2) analysis the characteristics users and difficulties experienced, (3) task analysis, it is identifying the main tasks performed by the users according to their needs, (4) concept analysis, it is determining the material presented on the media, and (5) objective analysis, it is formulating indicators of the application for child care services goals. The design step, what is conducted in the design and developed a mobile application-based parenting services on the Android OS. The development step is validation by media experts and material experts with continued revisions, and then testing or implementing media. The disseminate step is distribute media in Google Playstore.

\section{RESULT}

\subsection{The development of a mobile application for TPA Melati Dharma Wanita Persatuan UM}

The development of a mobile application for child care in TPA is a form of virtual learning facility, especially during the Covid-19 pandemic. There are 4 (four) menus available in the application including (a) the child's profile; (b) chat service for children's health; (c) child stimulation services; and (d) children's page containing identities and development reports.

The results of the assessment from media experts shows that the overall validation results from media experts are $89.52 \%$, and the category is very feasible.

While, the results of the assessment of material experts shows the percentage of the feasibility of $89.57 \%$ and is in the very feasible category. After the media is tested for feasibility, improvements are made, and the media is ready to be tested in the learning process.
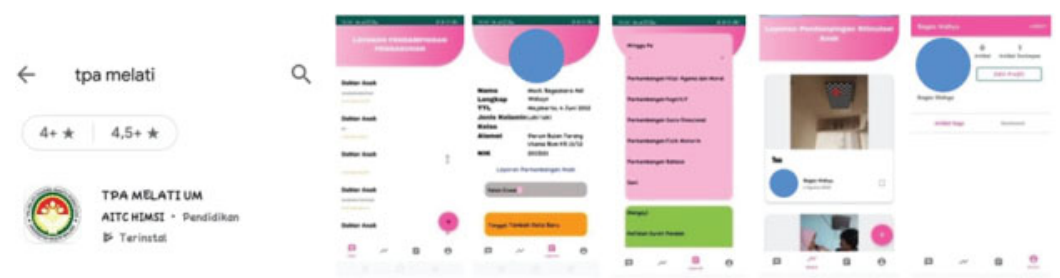

Figure 1. TPA Melati UM's application.

Percentage of Media Feasibility

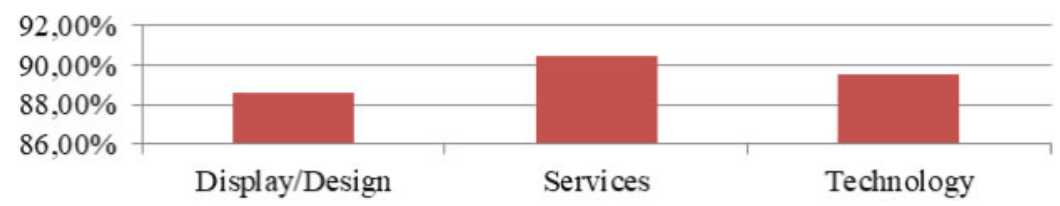

Figure 2. Percentage of media feasibility by validation experts. 


\section{Percentage of Materials Feasibility}

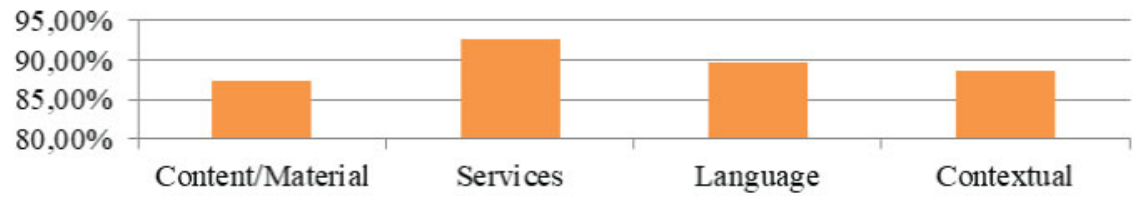

Figure 3. Percentage of materials feasibility by validation experts.

Percentage of Media Tested by Parents/Guardians of Students

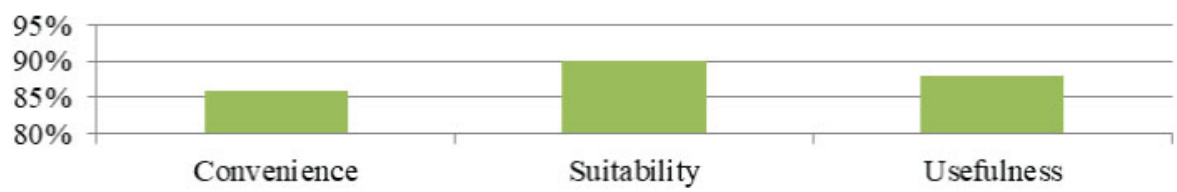

Figure 4. Percentage of media tested by parents/guardians of students as users.

The test results shows that the parents/guardian of students as user believes that the application has a very good value with a percentage of $88 \%$. The application developed is a very feasible to use, easy, in accordance with the characteristics of the user, and useful.

These results are supported by other research that mobile technology can increase parental involvement. In this case, there is collaboration between parents and teachers which is an important step for student achievement (Beecher \& Buzhardt 2016; Can 2016).

\subsection{Child care services in TPA Melati Dharma Wanita Persatuan UM}

Child care service

The child care services at TPA Melati UM are provided for children starting from the time they arrived until picked-up, including the setting of safe, comfortable, and protective facilities. In Covid-19 pandemic era, through the application has been developed, parents and teachers can take advantage of the progress report menu every week. Parent-school collaboration with mobile technology is positive to fulfill the need of children (Özdaml $l \&$ Y $\imath$ ld $l$ z 2014).

\section{Education service}

The educational services provided by TPA Melati UM are covering playing and learning activities both indoor and outdoor using Educative Game Tools (APE) to supports children's development. In Covid-19 pandemic era, educational services based on aspects of the development (religious and moral values, cognitive, socio-emotional, physical motor, language, and art) through the "child stimulation services" menu in application. The existence of two-way communication between parents and teachers can supports children's development (Kim 2020).

\section{Health and nutrition service}

The nutrition provided at TPA Melati UM is part of its services in the form of providing balanced nutritional food needed by children. The served food is cooked by the manager herself without artificial flavouring, and the menu was consulted with parents beforehand, according to the three pillars of service for health and nutrition: health services, nutritional intake, and psychosocial stimulation (Sadiah et al. 2020). In Covid-19 pandemic era, through a chat menu in applications, the health and nutrition services are still fulfilled and controlled. This menu helps parents to consult with a paediatricians in collaboration with TPA. This application helps various parties (the teacher, the parent, counsellors, health services, and the school management) to work together in fulfilling children's growth (Setyawan et al. 2016). 


\section{Facilities and infrastructure}

The facilities and infrastructure are in the form of indoor and outdoor facilities, learning infrastructure of buildings, and multipurpose rooms that can be used for playing and studying as well as for sleeping. There are also a kitchen and bathroom, supporting facilities in the form of equipment that supports clean and healthy lifestyle. In Covid-19 pandemic, the application is a media alternative for parents to get care services in TPA Melati UM as an educational institution in implementing distance learning so that it is still carried out well (Dhawan 2020).

\section{CONCLUSION}

The application for child care services had been validated by media experts (89.52\%) and material experts $(89.57 \%)$. In general, the application for child care services received very good category $(88 \%)$ from user regarding convenience, suitability, and usefulness of the application. The services provided by TPA Melati Dharma Wanita Persatuan UM can be accessed through the application so that students still get care services, educational services, health services, and infrastructure services in the Covid-19 pandemic.

\section{REFERENCES}

Ang, L. (2018). Conceptualising Home-Based Child Care: A Study of Home-Based Settings and Practices in Japan and England. International Journal of Early Childhood, 16.

Beecher, C., \& Buzhardt, J. (2016). Mobile technology to increase parent engagement. Interaction Design and Architecture(s), 28(1), 49-68.

B. T. Bowman and S. Donovan. (2010). Eager to Learn: Educating Our Preschoolers. National Academy Press.

Can, M. H. (2016). Use of mobile application: Means of communication between Parents and Class Teacher. World Journal on Educational Technology: Current Issues, 8(3), 252. https://doi.org/10.18844/ wjet.v8i3.834

Dewi, N. R., \& Akhlis, I. (2016). Pengembangan Perangkat Pembelajaran Ipa Berbasis Pendidikan Multikultural Menggunakan Permainan Untuk Mengembangkan Karakter Siswa. USEJ, 5(1), 1098-1108. https://doi.org/10.15294/usej.v5i1.9569

Dhawan, S. (2020). Online Learning: A Panacea in the Time of COVID-19 Crisis. Journal of Educational Technology Systems, 49(1), 5-22. https://doi.org/10.1177/0047239520934018

Gadsden, V. L., Ford, M., \& Breiner, H. (2016). Parenting matters: Supporting parents of children ages 0-8. In Parenting Matters: Supporting Parents of Children Ages 0-8. The National Academies Press. https://doi.org/10.17226/21868

Huang, C.Y., Cheah, C. S. L., Lamb, M. E., \& Zhou, N. (2017). Associations Between Parenting Styles and Perceived Child Effortful Control Within Chinese Families in the United States, the United Kingdom, and Taiwan. Journal of Cross-Cultural Psychology, 48(6), 795-812. https://doi.org/10.1177/0022022117706108

Kim, J. (2020). Learning and Teaching Online During Covid-19: Experiences of Student Teachers in an Early Childhood Education Practicum. International Journal of Early Childhood, 52(2), 145-158. https://doi.org/10.1007/s13158-020-00272-6

Oostdam, R., \& Hooge, E. (2013). Making the difference with active parenting; Forming educational partnerships between parents and schools. European Journal of Psychology of Education, 28(2), 337-351. https://doi.org/10.1007/s10212-012-0117-6

Özdaml $\iota$ F., \& Y $\iota l d l z$, E. P. (2014). Parents' Views towards Improve Parent-School Collaboration with Mobile Technologies. Procedia - Social and Behavioral Sciences, 131, 361-366. https://doi.org/10.1016/j.sbspro.2014.04.130

Sadiah, G. S., Romadhona, N. F., \& Gustiana, A. D. (2020). Penerapan Layanan Kesehatan Dan Gizi Dalam Anak Usia Dini (AUD). 17(1), 50-64.

Setyawan, S. H., Absari, D. T., Limanto, S., \& Andre. (2016). The design of mobile application for teacher and parents communication in Indonesian school. MATEC Web of Conferences, 58, 4-8. https://doi.org/10.1051/matecconf/20165803016

Stearns, J. A. (2019). Associations of friendship and children's physical activity during and outside of school_ A social network study. Population Health, 10.

Yulianingsih, W., Susilo, H., Nugroho, R., \& Soedjarwo. (2020). Optimizing Golden Age Through Parenting in Saqo Kindegarten. 405(Iclles 2019), 187-191. https://doi.org/10.2991/assehr.k.200217.039 